\title{
Solution Equilibrium Study of the Complexation of Co(II) and Zn(II) with Nicotinaldehyde Thiosemicarbazone
}

\author{
Dunkana Negussa Kenie ${ }^{1^{*}}$ and Satyanarayana $A^{2}$ \\ ${ }^{1}$ Department of Chemistry, College of Computational and Natural Sciences, Wollega University, \\ P.O. Box: 395, Nekemte, Ethiopia \\ ${ }^{2}$ Department of Physical and Nuclear Chemistry and Chemical Oceanography, Andhra University, \\ Visakhapatnam -530003, India
}

\begin{tabular}{|c|c|}
\hline Abstract & Article Information \\
\hline $\begin{array}{l}\text { The interaction of nicotinaldehyde thiosemicarbazone with } \mathrm{Co}(\mathrm{II}) \text { and } \mathrm{Zn}(\mathrm{II}) \text { was } \\
\text { investigated in SDS-water }(1.15 \% \mathrm{w} / \mathrm{v}) \text { at } 303 \mathrm{~K} \text { and ionic strength of } 0.1 \mathrm{~mol} \mathrm{dm}^{-3} \text {. The } \\
\text { speciation and stability constants of the metal complexes formed were determined by pH- } \\
\text { metric method. Protonated and simple mononuclear species in different protonation and } \\
\text { deprotonation states were identified. The corresponding formation constants calculated } \\
\text { using MINIQUAD- } 75 \text { computer program, and species distribution diagrams produced using } \\
\text { the HYS computer program. Selection of the best-fit chemical models was based on } \\
\text { statistical parameters. The results obtained from the study revealed that, the NTSC on } \\
\text { interaction with metal ions in solution, a series of mononuclear }\left[\mathrm{M}\left(\mathrm{LH}_{h}\right)\right](h=1,0) \text {, and bis- } \\
\text { mononuclear }\left[\mathrm{M}\left(\mathrm{L}_{2} \mathrm{H}_{\mathrm{h}}\right)\right](h=2,1,0,) \text { species were identified. }\end{array}$ & $\begin{array}{l}\text { Article History: } \\
\text { Received : 19-08-2015 } \\
\text { Revised : 24-09-2015 } \\
\text { Accepted : 25-09-2015 } \\
\text { Keywords: } \\
\text { Formation constant } \\
\text { Nicotinaldehyde } \\
\text { thiosemicarbazone } \\
\text { Metal complexes } \\
\text { *Corresponding Author: } \\
\text { Dunkana Negussa Kenie } \\
\text { E-mail: } \\
\text { dunkana11@yahoo.com }\end{array}$ \\
\hline
\end{tabular}

\section{INTRODUCTION}

Thiosemicarbazones and their metal complexes are compounds that possess antitumor, antibacterial, antifungal and antiviral properties. For example, Triapine ${ }^{\circledR}$ (3-aminopyridine-2-carboxaldehyde thiosemicarbazone) has been developed as an anticancer drug and has reached clinical phase II on several cancer types (Nutting et al., 2009; Ma et al., 2008). At large the activity of the ligand is greatly enhanced by the presence of a metal ion. Thiosemicarbazones are receiving more attention largely in areas of antitumor, antiaprotozoal, antibacterial or antiviral activities and in all cases their action has been shown to involve interaction with metal ions (Finch et al., 1999; Antholine et al., 1977; Beraldo and Gambino, 2004 ).

The arrays of compounds of thiosemicarbazones are very interesting in their use against cancer because of their topology which is important in selectivity. The presence of a metal ion almost systematically increases the activity or contributes to mitigate the side effects of the organic parent compounds (French and Blanz, 1965). The coupling of thiosemicarbazones with metals, gives good biological activity due to the synergistic effect. The main identified effects related to their anticancer activity are ribonucleotide reductase (RR) inhibition (Brockman et al., 1970), reactive oxygen species (ROS) production (Shao et al., 2006), topoisomerase II inhibition (Hall et al., 2000), mitochondria disruption (Yuan et al., 2004), and a multidrug resistance protein (MDR1) inhibition (Ludwig et al., 2006 and $\mathrm{Wu}, 2007)$. The metal complexes of thiosemicarbazone are also widely studied for their chemical and analytical purposes (Akinchan et al., 1996; Offiong, 1994; Sushil and Srivastava, 1985; Belicchi et al., 1986; Belicchi et al., 1992; Hingorani and Agarawala, 1990; Tempereni et al., 1995; Revathy and Palaniappan, 1990).

In solution thiosemicarbazones are known to exist in thiol form tautomerizing from the thione form. Complexation usually takes place via dissociation of the acidic proton, resulting in the formation of usually fourmembered or depending on the alkyl/aryl group a fivemembered chelate ring (Pal et al., 2002).

To understand the way thiosemicarabzones and their metal complexes are acting as anticancer agents, it is imperative to understand the solution equilibria of these compounds. With this interest the protonation constant and the stability constants of $\mathrm{Co}$ (II) and $\mathrm{Zn}$ (II) complexes of nicotinaldehyde thiosemicarbazone were studied and reported here under.

\section{MATERIALS AND METHODS}

\section{Material, Solutions and Apparatus}

All the chemicals used were of AnalaR or equivalent grade. Chlorides of Co (II) and Zn (II), EDTA disodium dehydrate, sodium hydroxide pellets, potassium hydrogen phthalate (KHP) and oxalic acid were purchased from E. Merck. Pro. analysis. All other solutions, including 
Dunkana Negussa and Satyanarayana

hydrochloric acid, sodium hydroxide, and sodium chloride, were prepared using doubly glass distilled water through which nitrogen gas was purged to expel any dissolved oxygen or carbon dioxide. Nicotinaldehyde thiosemicarbazone (NTSC) was supplied by Fluka, AR and Sodium chloride was obtained from BDH AnalaR.

The way the stock solution of metal chlorides, ligand (NTSC) solution, standardization of acid-base solutions were prepared following the standard procedures explained else were (Kenie and Satyanarayana, 2015).

A Control Dynamics pH-meter model APX $175 \mathrm{E} / \mathrm{C}$ in conjunction with a combination electrode $(0-14 \mathrm{pH}$ range) was used for $\mathrm{pH}$ measurements. The $\mathrm{pH}$ correction factor was calculated before each set of experimental titrations by Gran method (Gran, 1952; Gran, 1950; Giuseppe et al., 1979).

\section{Titration Procedure and Data Analysis}

Calvin-Wilson titration technique modified by Rossotti (Irving and Rossotti, 1953, 1954) was employed for the study of protonation and complex equilibria of the ligand (NTSC) in the same condition of the metal-ligand complexation. Titrations were carried out at $1: 1$ and 1:2 ratios of initial concentrations of metal to ligand in SDS $(1.15 \% \mathrm{w} / \mathrm{v})$-water mixture. The ligand is poorly soluble in water, and various $\mathrm{SDS} / \mathrm{H}_{2} \mathrm{O}$ solvent mixtures were tested as suitable media for aqueous solution equilibrium studies; $1.15 \%$ (w/v) SDS/ $\mathrm{H}_{2} \mathrm{O}$ was found to be sufficient for dissolution of the ligand at the concentration levels necessary for $\mathrm{pH}$ potentiometric titrations (i.e., $\geq 1-2 \mathrm{mM}$ ). In the titrations the upper $\mathrm{pH}$ limit of rejecting data was determined by the appearance of opalescence leading to precipitation indicated by a downward drift of the $\mathrm{pH}$ meter dial readings.
Sci. Technol. Arts Res. J., July-Sep 2015, 4(3): 145-149

For a system containing a metal ion and a ligand forming $\mathrm{N}$ complexes, the formation constant of a complex can be represented as,

$$
m \cdot \mathrm{M}+\mathrm{l} . \mathrm{L}+h \mathrm{H} \rightleftharpoons \mathrm{M}_{m} \mathrm{~L} / \mathrm{H}_{h}
$$

and the overall formation constant is given by,

$$
\beta_{m / h}=\left[\mathrm{M}_{m} \mathrm{~L} / \mathrm{H}_{h}\right]_{\mathrm{i}} /[\mathrm{M}]_{\mathrm{i}}^{m} \cdot[\mathrm{L}]_{\mathrm{i}}^{l} \cdot[\mathrm{H}]_{\mathrm{i}}^{h}
$$

Where $[M]_{i},[L]_{i}$ and $[H]_{i}$ are the free concentrations of metal, ligand and hydrogen ion respectively at $i^{\text {th }}$ experimental point. Different species in solution possess different values of stoichiometric coefficients $m, l$ and $h$. Positive value of $\mathrm{h}$ indicates protonated species and negative value indicates either deprotonated or hydroxylated species. The potentiometric titration data obtained was subjected to analysis by Miniquad-75 program (Gans, 1976).

The stoichiometry and stability constants of the species formed in solutionwere determined by examining various chemically possible composition models for the systems studied. Thebest-fit models were selected on the basis of $U$ (sum of the squares of residuals in mass balance equations), standard deviations in formation constants and other statistics like $x^{2}$ test which tests the distribution of errors against a normal one. Species distribution diagrams for all the systems under study were generated using HYSS (Alderighi, 1999) program.

\section{RESULTS AND DISCUSSION}

\section{Protonation of Nicotinaldehyde Thiosemicarbazone (NTSC)}

The protonation and deprotonation equilibria of NTSC are shown in Figure 1. The best-fit model obtained using Miniquad-75 program for NTSC was reported in our previous work (Kenie and Satyanarayana, 2015).

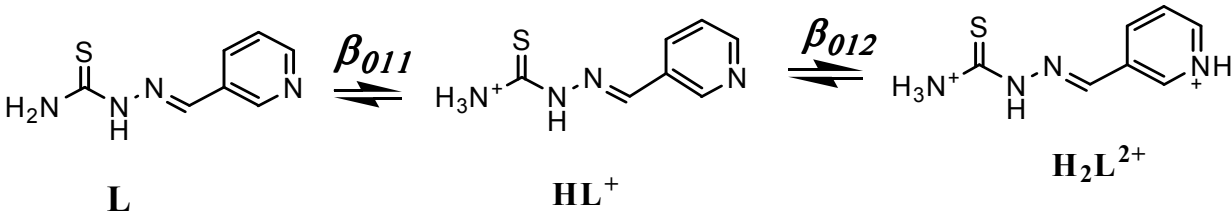

Figure 1: Protonation and deprotonation equilibria of NTSC

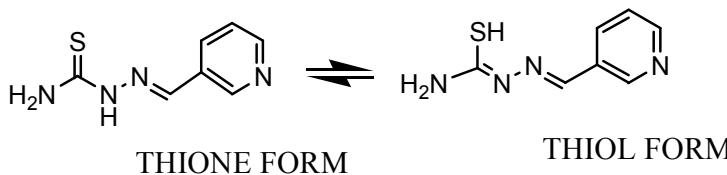

Figure 2: Thione- thiol Tautomerisation of NTSC .

\section{Complex Formation of NTSC with Divalent Metal lons}

The potentiometric titration data for $1: 1$ and 1:2 metal to ligand concentration ratios for different metal ions was used to calculate the formation constants of mononuclear complexes. The acquired data was first subjected to analysis by classical procedures (Irving and Rossotti, 1953) to get the formation constants of simple mononuclear complexes like $\mathrm{ML}, \mathrm{ML}_{2}$ etc. Simulated titration curves were then generated using a computer program SOPHD (Rao et al., 1984) to see whether these species satisfy the experimental data. The simulated titration curves thus obtained were plotted along with the experimental ones to identify the regions of $\mathrm{pH}$ where they differ. Titration curves for the systems for all the compositions are shown in Figure 3. The wide difference between the simulated and experimental curves reveals the presence of other major species in addition to simple mono-nuclear complexes. Different chemical models containing chemically plausible species depending on the nature of the ligand, metal and the $\mathrm{pH}$ region of difference in the curves were tested using the Miniquad-75 program. The required initial estimates of the formation constants were calculated basing on the formation constants of simple complexes and protonation/ deprotonation constants of the ligand.

The experimental titration data indicated that the ligand was efficient metal-ion chelator in a wide $\mathrm{pH}$ range 


\section{Dunkana Negussa and Satyanarayana}

for both metal ions. It should be noted, however, that the ligands were not able to keep the metal ions in solution at a metal to-ligand ratio of $1: 1$ and $1: 2$ at highly basic $\mathrm{pH}$, and precipitation occurred. The complex formation processes with the ligand start at low $\mathrm{pH}(\mathrm{pH} \approx 2.3)$ in the case of both metal ions. The stoichiometries of the metal
Sci. Technol. Arts Res. J., July-Sep 2015, 4(3): 145-149

complexes and the stability constants furnishing the best fits to the $\mathrm{pH}$-potentiometric experimental data together with equilibrium constants are given in Table 1.The data reveal the formation of mono-ligand complexes and bisligand complexes.
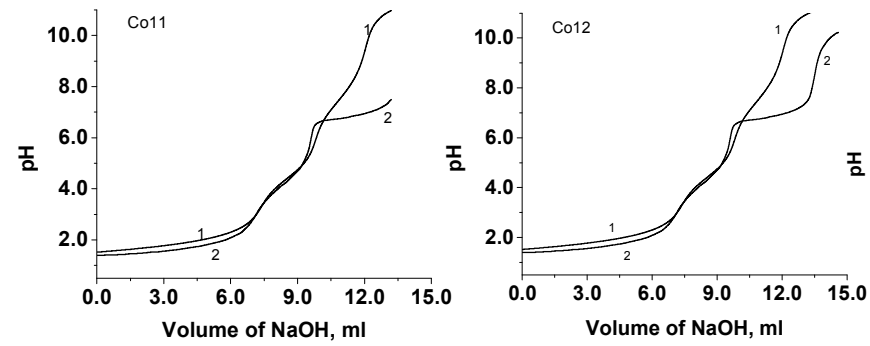

(a)
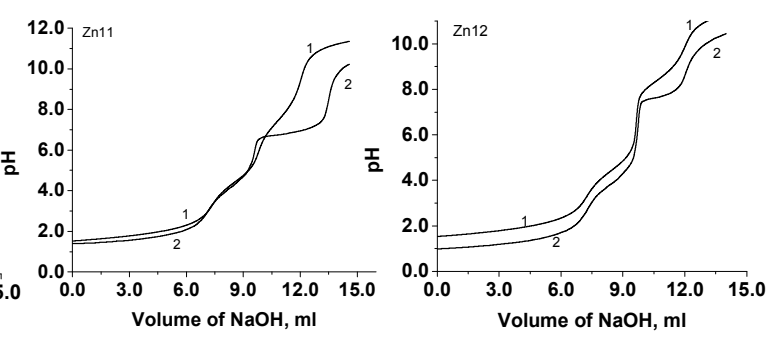

(b)

Figure 3: Simulated and experimental titration curves for (a) cobalt (II)-NTSC and (b) zinc (II)-NTSC systems for 1:1, and $1: 2$ compositions in $1.15 \% \mathrm{w} / \mathrm{v}$ SDS-water mixture. (1. Simulated titration curve 2 . Experimental titration curve)

The results of the analysis i.e., the stoichiometry and the overall formation constants of various species giving the best fit to the experimental data for all the systems are given in Table 1. The best-fit models contain protonated, and unprotonated mononuclear species. The investigation revealed that the best-fit models $\mathrm{ML}$ and
MLH for $1: 1$ ratio ; $\mathrm{ML}_{2}, \mathrm{ML}_{2} \mathrm{H}$, and $\mathrm{ML}_{2} \mathrm{H}_{2}$ for $1: 2$ ratio species between the ligand and $\mathrm{Co}(\mathrm{II})$ and $\mathrm{Zn}(\mathrm{II})$ ions are formed depending on $\mathrm{pH}$. The formation constants are in good agreement with Irving-Williams order (Irving and Williams,1948 and 1953 ) i.e. $\mathrm{Mn}^{\prime \prime}<\mathrm{Co}^{\prime \prime}<\mathrm{Ni}^{\prime \prime}<\mathrm{Cu}^{\prime \prime}$ $>\mathrm{Zn}^{\prime \prime}$.
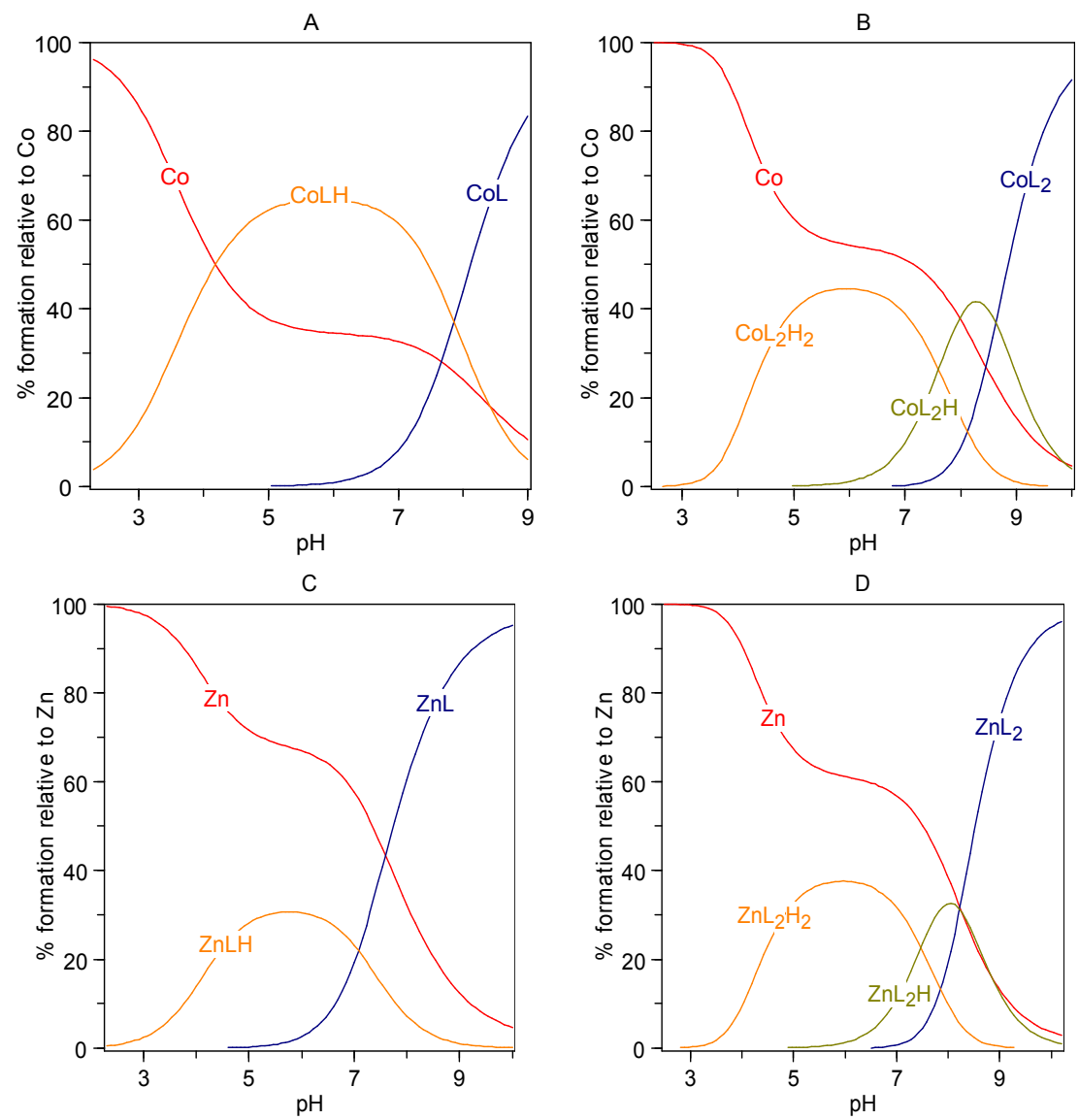

Figure 4: Species distribution diagrams of $M^{\prime \prime}-N T S C$ systems for 1:1, and 1:2 ( $M: L$ ) concentration ratios compositions in $1.15 \%$ w/v SDS-water mixture. ((A). Co"-NTSC(1:1), (B). Co"-NTSC(1:2), and (C). Zn"-NTSC(1:1) and (D). Zn"-NTSC(1:2) 
Table 1: Best-Fit models for NTSC- metal ion systems (Temp. $=30 \pm 1^{\circ} \mathrm{C}$ and ionic strength, $I=0.1 \mathrm{~mol} \mathrm{dm}^{-3}$ ) in SDSwater mixture $1.15 \%(\mathrm{w} / \mathrm{v})$

\begin{tabular}{|c|c|c|c|c|c|c|c|c|c|c|}
\hline Metal & \multicolumn{3}{|c|}{$\log \beta_{\operatorname{mlh}}(S D)$} & $\mathrm{Np}$ & $\mathbf{U}_{\text {corr }}$ & $\chi^{2}$ & Skewness & Kurtosis & R-Factor & pH-Range \\
\hline \multicolumn{11}{|c|}{$1: 1$} \\
\hline & 110 & 111 & & & & & & & & \\
\hline $\mathrm{Co}(\mathrm{II})$ & $05.36(6)$ & $13.21(5)$ & & 62 & 3.8 & 14.20 & -0.35 & 4.41 & 0.0041 & $2.5-9.0$ \\
\hline $\mathrm{Zn}(\mathrm{II})$ & $05.24(3)$ & $12.31(2)$ & & 36 & 0.9 & 16.07 & -0.48 & 6.68 & 0.0017 & $2.5-10.0$ \\
\hline \multicolumn{11}{|c|}{$1: 2$} \\
\hline & 120 & 121 & 122 & & & & & & & \\
\hline $\mathrm{Co}(\mathrm{II})$ & $08.58(7)$ & $17.21(6)$ & $24.81(8)$ & 42 & 2.5 & 12.30 & -0.50 & 5.26 & 0.0054 & $2.5-10.2$ \\
\hline $\mathrm{Zn}(\mathrm{II})$ & $08.89(7)$ & 17.11(8) & $24.58(4)$ & 66 & 0.8 & 9.45 & 0.09 & 6.55 & 0.0025 & $2.5-10.10$ \\
\hline
\end{tabular}

Ucorr=Ux10 $10^{-8} \mathrm{NP}-\mathrm{m} ; \mathrm{NP}=$ number of points; $\mathrm{m}=$ number of species; $\mathrm{SD}=$ standard deviation

The species distribution diagrams for metal-ligand systems (Figure 4) give the percentage of formation of various species as a function of $\mathrm{pH}$. For $1: 1$ and $1: 2$ compositions at $\mathrm{pH}$ below $\sim 6.0$, the protonated species $\mathrm{MLH}$, and $\mathrm{ML}_{2} \mathrm{H}_{2}$ are prevalent for the metal ions under study and the species $\mathrm{ML}_{2} \mathrm{H}$ appear in between $\mathrm{pH} 6.0$ and 8.0 for both metal ions. In the protonated species $\mathrm{MLH}, \quad \mathrm{ML}_{2} \mathrm{H}$ and $\mathrm{ML}_{2} \mathrm{H}_{2}$ probably the protons can presumably be attributed to the non-coordinating pridinic nitrogen and the NTSC is invoved in bonding as a bidentate with the metal ions through the sulfur, in thione form and iminic nitrogen atom. The species $\mathrm{ML}_{2} \mathrm{H}_{2}$ with increase in $\mathrm{pH}$ loses a proton on non-bonding side and forms $\mathrm{ML}_{2} \mathrm{H}$. Beyond $\mathrm{pH} 4.0$ simple complexes like $\mathrm{ML}$ and $\mathrm{ML}_{2}$ appear in solutions of compositions $1: 1$ and 1:2 $(\mathrm{M}: \mathrm{L})$, in which neutral form of NTSC participates in complexation as a bidentate bonding through thiol form of sulfur via deprotonation of the $-\mathrm{SH}$ group and iminic nitrogen atom. This is the typical coordination for the pyridinecarbaldehyde thiosemicarbazones (West et al., 1993).

The percentage of formation of the diprotonated complexes is $35 \%$ and $45 \%$ for $\mathrm{Zn}$ (II) and $\mathrm{Co}$ (II) respectively. The formation of the simple system is dominant beyond $\mathrm{pH} 7$ reaching $80-97 \%$ for different metal ions. The formation of these species may be due to the tautomerisation of the thione to thiol form (Fig.2) of the ligand in bonding.

\section{CONCLUSION}

The results obtained clearly indicate that nicotialdehyde thiosemicarbazone $(\mathrm{L})$ possesses a number of potential donor atoms. Depending on $\mathrm{pH}$, the ligand exists in various protonated and deprotonated forms, $\mathrm{LH}_{2}{ }^{2+}, \mathrm{LH}^{+}$, and $\mathrm{L}$. The protonation is at the pyridine nitrogen atom and deprotonation is from the thiol forms at higher $\mathrm{pH}$. On interaction with metal ions in solution, a series of mononuclear $\left[\mathrm{M}\left(\mathrm{LH}_{\mathrm{h}}\right)\right](h=1,0)$, and bismononuclear $\left[\mathrm{M}\left(\mathrm{L}_{2} \mathrm{H}_{\mathrm{h}}\right)\right](h=2,1,0$,$) species were$ identified. The formation constants and species distribution indicate strong complexation in most of the cases. It was also concluded that the formation of mono and bis-ligand protonated complexes is favourable with both metal ions in the physiological $\mathrm{pH}$ range.

\section{Conflict of Interest}

Conflict of interest none declared.

\section{REFERENCES}

Akinchan, N.T., Akinchan, R., Drozdzewski, P.M. (1996). Nuclear magnetic resonance and vibrational spectral studies on platinum(II) complexes of thiosemicarbazone derived from fluorenone. Polish Journal of Chemistry 70(2): 171-179.

Alderighi, L., Gans, P., lenco, A., Peters, D., Sabatini, A., Vacca, A. (1999). Hyperquad simulation and speciation (HySS): a utility program for the investigation of equilibria involving soluble and partially soluble species. Coordination Chemistry Review 184: 311-318.

Antholine, W., Knight, J., Whelan, H., Petering, D.H (1977). Studies of the reaction of 2-formylpyridine thiosemicarbazone and its iron and copper complexes with biological systems. Molecular Pharmacology 13: 89-98.

Belicchi, M.F., Gasparri, G.F., Leporati, E.. Pelizzi, C. Tarasconi, P., Tosi, G. (1986). Thiosemicarbazones as co-ordinating agents. Solution chemistry and X-ray structure of pyridoxal thiosemicarbazone trihydrate and spectroscopic properties of its metal complexes. Journal of the Chemical Society, Dalton Transactions 11: 24552462 .

Belicchi, M.F., Giovanna, G.F., Corrado, P., Pieralberto, T. (1992). Thiosemicarbazones as co-ordinating agent. Part 5. Zinc complexes derived from methyl pyruvate and pyridoxal thiosemicarbazones. Journal of the Chemical Society, Dalton Transactions 14: 2153- 2160.

Beraldo, H. and Gambino, D. (2004). The wide pharmacological versatility of semicarbazones, thiosemicarbazones and their metal complexes. MiniReviews in Medicinal Chemistry 4: 31-39.

Brockman, R.W., Sidwell, R.W., Arnett, G., Shaddix, S. (1970). Heterocyclic thiosemicarbazones: correlation between structure, inhibition of ribonucleotide reductase, and inhibition of DNA viruses. Proceedings of the Society for Experimental Biology and Medicine 133: 60914.

Finch, R.A., Liu, M.C., Cory, A.H., Cory, J.G., Sartorelli, A.C. (1999). Triapine (3-aminopyridine-2-carboxaldehyde thiosemicarbazone 3-AP): an inhibitor of ribonucleotide reductase with antineoplastic activity. Advances in Enzyme Regulation 39: 3-12.

French, F.A., Blanz, E.J.J. (1965). The carcinostatic activity of alpha- $(\mathrm{N})$ heterocyclic carboxaldehyde thiosemicarbazones. I. Isoquinoline-1-carboxaldehyde thiosemicarbazone. Cancer Research 25: 1454-8.

Gans, P., Sabatini, A. and Vacca, A. (1976). An Improved Computer Program for the Computation of Formation Constants from Potentiometric Data. Inorganica Chimica Acta 18: 237-239.

Giuseppe Arena., Enrico Rizzarelli., Silvio Sammartano. and Carmelo Rigano. (1979). A non-linear least-squares 


\section{Dunkana Negussa and Satyanarayana}

approach to the refinement of all parameters involved in acid-base titrations. Talanta 26(1): 1-14.

Gran, G. (1950). Determination of the Equivalence Point in potentiometeric Titratins. Acta Chemica Scandinavica 4: 559-577.

Gran, G. (1952). Determination of the equivalence point in potentiometric titrations. Part II. Analyst 77: 661-671.

Hall, I.H., Lackey, C.B., Kistler, T.D., Durham, R.W. Jr, Jouad, E.M., Khan, M., Thanh, X.D., Djebbar-Sid, S. Benali-Baitich, O., Bouet, G.M. (2000). Cytotoxicity of copper and cobalt complexes of furfural semicarbazone and thiosemicarbazone derivatives in murine and human tumor cell lines. Pharmazie 55(12): 937-41.

Hingorani, S., Agarawala, B.V. (1990). Structural investigations of $\mathrm{Pd}(\mathrm{II})$ and $\mathrm{Pt}(\mathrm{II})$ complexes with $\mathrm{O}$ vanillin thiosemicarbazone and 4phenylthiosemicarbazone and their mixed ligand complexes. Spectroscopy Letters 23(8): 1097-1109.

Irving, H.M. and Rossotti, H.S. (1954). The Calculation of Formation Curves of Metal Complexes from $\mathrm{pH}$-Titration Curves in Mixed Solvents. Journal of the Chemical Society (Resumed) 2904-2910

Irving, H.M. and Williams, R.J.P. (1948). Order of Stability of Metal Complexes. Nature (London) 162: 746-747.

Irving, H.M. and Williams, R.J.P. (1953). The stability of transition-metal complexes. Journal of the Chemical Society (Resumed) 167: 3192-3210.

Irving, H.M., Rossotti, H.S. (1953). Methods for computing successive stability constants from experimenta formation Curves. Journal of the Chemical Society (Resumed) 3397-3405

Kenie, D.N. and Satyanarayana, A. (2015). Protolitic Equilibria and Stability Constants of $\mathrm{Mn}$ (II) and $\mathrm{Ni}$ (II) Complexes of 3-formylpyridine Thiosemicarbazone in Sodium Dodecyl Sulphate(SDS-Water Mixture. Science, Technology and Arts Research 4(1): 74-79.

Ludwig, J.A., Szakács, G., Martin, S.E., Chu, B.F., Cardarelli, C., Sauna, Z.E., Caplen, N.J., Fales, H.M., Ambudkar, S.V., Weinstein, J.N., Gottesman, M.M. (2006). Selective toxicity of NSC73306 in MDR1-positive cells as a new strategy to circumvent multidrug resistance in cancer. Cancer Research 66(9): 4808-15.

Ma, B., Goh, B.C., Tan, E.H., Lam, K.C., Soo, R., Leong, S.S., Wang, L.Z., Mo, F., Chan, A.T., Zee, B., Mok, T. (2008). A multicenter phase II trial of 3-aminopyridine-2carboxaldehyde thiosemicarbazone (3-AP, Triapine) and gemcitabine in advanced non-small-cell lung cancer with pharmacokinetic evaluation using peripheral blood mononuclear cells. Invest New Drugs 26(2): 169-73.
Sci. Technol. Arts Res. J., July-Sep 2015, 4(3): 145-149

Nutting, C.M., van Herpen, C.M.L., Miah, A.B., Bhide, S.A., Machiels, J.P., Buter, J., Kelly, C., de Raucourt, D., Harrington, K.J. (2009). Phase II study of 3-AP Triapine in patients with recurrent or metastatic head and neck squamous cell carcinoma. Annals of Oncology 20(7): 1275-1279.

Offiong, O.E. (1994). Synthesis and spectral studies of platinum metal complexes of benzoin thiosemicarbazone. Spectrochimica Acta Part A: Molecular Spectroscopy 50A(13): 2167-2175.

Pal, I., Basuli, F., and Bhattacharya, S. (2002) Thiosemicarbazone complexes of the platinum metals. A story of variable coordination modes. Proceedings of the Indian Academy of Sciences: Chemical Sciences 114(4): 255-268.

Revathy, V., Palaniappan, R.A. (1990). Seletive and rapid spectrophotometric determination of platinum(II). Indian Journal of Chemistry: Section A 29: 197.

Sambasiva Rao, R., Satyanarayana, A. and Krishna Rao, P.V. (1984). Procedings of the Summer Simulation Conference 563.

Shao, J., Zhou, B., Di Bilio, A.J., Zhu L., Wang T, Qi, C., Shih, J., Yen, Y. (2006). A Ferrous-Triapine complex mediates formation of reactive oxygen species that inactivate human ribonucleotide reductase. Molecular Cancer Therapeutics 5: 586-592.

Sushil (Nee Bathla), P., Srivastava, T.S. (1985). Platinum(II) complexes of cyclohexanone and cycloheptanone thiosemicarbazones. Indian Journal of Chemistry: Section A 24(3): $240-241$.

Tempereni, M.L.A., Dos Santos, M.R., Paoli Monteiro, V.R (1995). Spectroscopic study of the isomerization of Z- to E-pyridine-2-formyl thiosemicarbazone. Spectrochimica Acta Part A: Molecular and Biomolecular Spectroscopy 51(9): 1517-1524

West, D.X., Liberta, A.E., Padhye, S.B., Chikate, R.C., Sonawane, P.B., Kumbhar, A.S., Yerande, R.G. (1993). Thiosemicarbazone complexes of copper(I1): structural and biological studies. Coordination Chemistry Reviews123: 49-71.

Wu, C., Shukla, S., Calcagno, A.M., Hall, M.D., Gottesman, M.M., Ambudkar, S.V. (2007). Evidence for dual mode of action of a thiosemicarbazone, NSC73306: a potent substrate of the multidrug resistance linked ABCG2 transporter. Molecular Cancer Therapeutics 6: 3287-96.

Yuan, J., Lovejoy, D.B., Richardson, D.R. (2004). Novel di-2pyridyl-derived iron chelators with marked and selective antitumor activity: in vitro and in vivo assessment. Blood 104: 1450-1458. 